\title{
A Brief Political Economy of Energy Subsidies in the Middle East and North Africa
}

\author{
Laura El-Katiri and Bassam Fattouh ${ }^{1}$
}

\begin{abstract}
Energy subsidies are among the most pervasive and controversial fiscal policy tools used in the Middle East and North Africa (MENA). In a region with few functioning social welfare systems, subsidised energy prices continue to form an important social safety net, albeit a highly costly and inefficient one. In the MENA region's oil and gas producing countries, low energy prices have also historically formed an important element of an unwritten social contract, where governments have extracted their countries' hydrocarbon riches in return for citizens' participation in sharing resource rents. While it is clear that energy subsidy reform will not be the only variable at play, its potential socio-economic dividends are important factors for enabling some common regional objectives - sustainable fiscal policies, fiscal space to invest in key areas, and a more efficient and equitable distribution of scarce resources - to be achieved, helping to promote a more stable political status quo in the long term. If accommodated by effective mitigation measures, reforming energy subsidies in the MENA region's middleincome economies could be a powerful tool for governments - addressing those very profound socio-economic grievances that have contributed to the outbreak of political protest and, in some cases, to an intensification of domestic infighting over political control. In this paper, we look at some of the MENA region's potential avenues for reform. While the past has demonstrated the political difficulty of reforming energy prices, recent experience also shows that the reform of energy subsidies can be achieved, if accompanied by a set of enabling factors.
\end{abstract}

\section{Introduction}

Energy subsidies are among the most pervasive and controversial fiscal policy tools in the Middle East and North Africa (MENA). Their reform continues to be difficult, from a political, economic and social perspective, due to the original objectives of these measures-such as the need to protect the interests of

1 A version of this article was published as working paper (https://www.oxfordenergy.org/ wpcms/wp-content/uploads/2015/o2/MEP-11.pdf).

(C) LAURA EL-KATIRI AND BASSAM FATTOUH, 2017 | DOI 10.1163/9789004336452_005

This is an open access chapter distributed under the terms of the CC-BY-NC License. 
low-income households and to foster domestic industrial growth. In a region with few functioning social welfare systems, subsidised energy prices continue to form an important social safety net, albeit a highly costly and inefficient one. In the MENA region's oil and gas producing countries, low domestic energy prices have also historically formed an important element of an unwritten social contract, where governments extract their countries' hydrocarbon riches, in return compensating their citizens through a variety of direct and indirect channels, including subsidies and other welfare benefits (El-Katiri et al., 2012; El-Katiri, 2013a). Energy subsidies hence play a pivotal role in a complex state-citizen relationship, a relationship that has come under increasing scrutiny in many Arab countries since the onset of the Arab uprisings in 2010.

The four years or more since protests erupted in Tunisia in December 2010, and the widespread regional unrest later summarised under the popularised term the 'Arab Spring', have placed the issue of greater socio-economic justice at the heart of MENA politics. In a way this has complicated, and in many cases delayed, overdue energy pricing reforms in a number of regional economies, as governments have feared that rising living costs would only intensify popular turmoil. On the other hand, despite being widely perceived as a fundamental economic and social benefit, energy subsidies form an important part of the socio-economic problems, and of the vastly distorted economic incentives, that plague the economies of the MENA region. The reform of energy pricing systems is also a complex process, which often requires structural changes to ownership and control over some of the most crucial assets of the state in the Middle East—oil, gas and electricity, together with their accompanying distribution infrastructure and networks. In lower- and middle-income countries, measures for reforming energy prices, if not accompanied by appropriate mitigation measures (such as a more effective and transparent social safety system), have an adverse effect on the disposable incomes of the poor and the aspiring middle classes.

There are also intra-regional differences behind the drivers of reform. The fiscal pressures associated with energy subsidies are a primary driver for reform in many of the region's lower- and middle-income countries, particularly those in need of financial support from international institutions such as the World Bank and the International Monetary Fund (IMF). But the recent decline in international oil prices (since the second half of 2014), coupled with rising fiscal break-even prices in many oil-exporting countries, has also provided relatively strong incentives for the wealthier oil and gas producers to consider their respective domestic energy-pricing frameworks. This is in addition to the long-term consequences that many oil producers face as they continue to divert increasing volumes of oil and gas away from export markets to satisfy rapidly growing domestic demand, at prices far below world market levels. 
In this paper, we look at some of the MENA region's potential avenues for reform. While the past has demonstrated the political difficulty of reforming energy prices, recent experiences in several MENA economies also show that the reform of energy subsidies can be achieved, if accompanied by a set of enabling factors. The rest of the paper proceeds as follows: Section 2 provides a brief background on energy subsidies in the MENA region; Section 3 looks at some of the reform experiences in the region; Section 4 concludes.

\section{A Brief Background on Energy Subsidies}

\subsection{Issues with Measuring Energy Subsidies}

Energy subsidies are neither straightforward to define nor simple to measure; this tends to complicate any meaningful debate around them. There is no commonly agreed definition of what constitutes a subsidy, and this fact-in part-is reflected in the continued inability of major international organisations such as the World Bank, the United Nations Development Programme (UNDP), and Organization of the Petroleum Exporting Countries (OPEC) to agree on common terms. ${ }^{2} \mathrm{~A}$ widely used definition considers a subsidy as:

... any measure that keeps prices for consumers below the market level or keeps prices for producers above the market level, or that reduces costs for consumers and producers by giving direct or indirect support.

DE MOOR and CALAMAI, 1997, 1

It is clear from the above definition that many governments' actions can be categorised as involving assistance, including subsidies (in-kind, cash or credit, or relating to tax or procurement). Some of these are on-budget or explicit subsidies that constitute explicit transfers made by the government to either the producer or the consumer receiving the subsidy, registered in the state's budget. For instance, a government may mandate that a public utility set the selling price below the cost of production. The government then finances that public utility's losses by transferring funds from the general budget. ${ }^{3}$ Energy

2 IEA et al. (2010) notes the existence of a major disagreement among international organisations concerning the choice of the reference price, and that consequently 'a commonly agreed definition of subsidies has proven a major challenge in the G-2o context and countries have decided to adopt their own definition of energy subsidies'.

3 The budget records of many countries (including Egypt) show how this concept underlies the measurement of subsidies in the economy. 
subsidies can also be cross-financed between different energy user groups. Cross-subsidies occur when tariffs below the cost of production are charged, to household users for instance, and the revenue shortfall is offset by increasing industrial/commercial sector tariffs above cost levels. Countries such as Lebanon, Yemen, Egypt, Libya, and Syria all charge their industrial customers considerably higher electricity prices than charged to residential customers, suggesting some form of cross-subsidisation. ${ }^{4}$

But there is also the question of the benchmark against which domestic prices should be compared. For instance, the national oil company can be mandated to sell petroleum products to the domestic market at below international prices but above production costs. In this case, the national oil company does not incur financial losses, and hence the government does not need to make an explicit transfer to compensate for those losses. Nevertheless, there is still an implicit cost involved, which represents the opportunity cost (the economic rent/revenue wasted by the failure to sell oil at higher, market prices). This entails a transfer from the government to the final consumers, even though such a transfer does not appear explicitly on state oil companies' records or in the government budget. If this foregone revenue had been collected, it could have been used by the government in a variety of ways, including to reduce the budget deficit and the size of the public debt; to increase expenditure in more productive areas such as infrastructure, education or health; by redistributing it directly to its people through cash transfers; or to reduce, where applicable, taxation (Gupta et al., 2003). Implicit subsidies are less transparent and more difficult to calculate. They typically occur in oil producing countries, where mostly state-owned oil companies produce, refine and market petroleum products.

Based on the price-gap approach-which measures the gap between the subsidised price and a benchmark price to reflect the opportunity cost (defined as the supply cost of an energy product including transport and distribution costs) - a recent IMF report estimates pre-tax energy subsidies in the MENA region as having reached USD 237 billion in 2011, equivalent to 48 per cent of world subsidies, 8.6 per cent of regional GDP, and 22 per cent of government revenue (Sdralevich et al., 2014). These figures, however, should be treated with caution given the many caveats to using the price-gap approach in some contexts. Issues such as the production of joint products (for instance crude oil, natural gas, and natural gas liquids (NGLs)), the availability of spare capacity in some Arab oil-producing countries, and the ability of key Arab oil

4 Since in all these countries public utilities do not recover their costs, this form of crosssubsidisation is nevertheless imperfect, and does not prevent the sector from systemic loss making. 
exporters to influence international oil prices could affect the measurement of subsidies. ${ }^{5} \mathrm{~A}$ recent study by the IMF broadens the definition of an energy subsidy to:

... [a post-tax energy subsidy, which arises] when consumer prices are below supply costs plus a tax to reflect environmental damage and an additional tax applied to all consumption goods to raise government revenues.

COADY ET AL., 2015, 1

Based on this definition, global energy subsidies are estimated at a massive USD 5.3 trillion for 2015 , or 6.5 per cent of global GDP, despite the recent fall in the oil price. This higher estimate of global energy subsidies results from the inclusion of components such as local air pollution, global warming, and other (non-internalised) domestic externalities in the post-tax energy price.

\subsection{Energy Subsidies and MENA Fiscal Stability}

As has become evident throughout the first decade of the twenty-first century, energy subsidies constitute a significant fiscal burden. With rising world market prices for oil and natural gas since the turn of the new millennium, the MENA region's parallel surge in domestic demand has translated into a rapid growth in fiscal expenditure on energy subsidies in importing countries such as Morocco, Egypt, Jordan, Syria, and Lebanon. Egypt's expenditure on energy subsidies reached a staggering USD 21 billion (EGP 143.7 billion) in the financial year 2013/14 - a figure equivalent to 19.5 per cent of total government spending, or almost the entire value of aid received by Egypt from Middle Eastern donors since mid-2012. ${ }^{6}$ Yemen's energy subsidy bill for 2013/14 was most recently estimated to be around USD 3.5 billion, a third of government expenditure and in excess of the country's budgeted deficit of USD 3.2 billion in that fiscal year (MEES, 2014h;Ghobari and El Gamal, 2014). The recent fall in the oil price comes as a welcome relief to these oil importers, but such relief could prove temporary, given that the future trajectory of oil prices remains highly uncertain.

5 A report notes that the price-gap method has limitations, which apply particularly in the case of countries with large endowments of energy resources (IEA et al., 2010).

6 MEes (2014a); authors' estimates of Gulf and Turkish aid paid to Egypt since the Morsi regime assumed power until February 2014 (around USD 24.5 billion). It is important to note that in measuring energy subsidies, Egypt only considers the actual expenditure on subsidies and not the opportunity cost. Based on the opportunity cost, the size of the subsidy would be much higher. 
A parallel problem related to current energy pricing in oil and gas producing countries-and in countries, such as Egypt, that are net importers of some fuels-is the medium- and long-term effect that current pricing policies have on these countries' own domestic production, and hence on their future revenue streams. Low domestic energy prices in many oil and gas producing countries provide a poor incentive for independent oil and gas companies to invest in new exploration and upstream development projects. Natural gas is the energy source most affected by domestic pricing policies - reflected in the poor fiscal terms offered to oil and gas companies considering investment opportunities. This will become increasingly important as a larger proportion of Middle East oil and gas becomes more expensive to produce. The development of gas reserves has hence lagged decades behind the Middle East's massive gas resource endowment undermining the long-term supply potential of the region.

The MENA economies' exceptionally high reliance on oil and natural gastradable fossil fuels whose world market prices fluctuate significantly - has also made the region highly vulnerable to international commodity price cycles. Energy subsidies have also been shown to be strong, procyclical 'destabilisers' in oil- and gas-importing countries across MENA, as government spending on subsidies increases during economic boom times along with rising demand, and declines as economic activity falls (Sdralevich et al., 2014, 21-22; IMF, 2013, 37-40). Several studies have demonstrated the negative consequences of procyclical spending in developing economies (Lane, 2003; Abdih et al., 2010; Kaminsky et al. 2004; Erbil, 2011), including the effect of commodity cycles on political stability over the medium and long term. ${ }^{7}$

\subsection{Energy Subsidies and Social Equity}

The widespread use of energy subsidies in developing countries continues to be widely defended on the basis of social security and ensuring access to energy. However, energy subsidies are largely inequitable as they naturally accrue most to the largest users - energy-intensive industries and middle- to highincome households. ${ }^{8}$ Petroleum product subsidies in particular benefit primarily the urban middle class, and households that can afford a car. In a recent study, the IMF found that the poorest quintiles in Egypt, Jordan, Mauritania, Morocco, and Yemen receive only about $1-7$ per cent of total diesel subsidies, while the richest quintiles receive subsidies to the tune of $42-77$ per cent of

7 E.g. Collier and Hoeffler (1998).

8 This also, where applicable, relates to natural gas/LPG. Kerosene, by contrast, tends to be proportionately consumed most by lower-income households, although substantial leakages exist to higher income groups. See e.g. Alderman (2002); Clements et al. (2003); Coady et al. (2006); Hope and Singh (1999). 
the total. In Egypt, the poorest 40 per cent of the population receives only 3 per cent of direct gasoline subsidies, 7 per cent of natural gas subsidies, and 1o per cent of diesel subsidies (Sdralevich et al., 2014).

Energy subsidies, many of which leak to higher income groups and industries, could otherwise have been invested in alternative channels-free public health and education, infrastructure improvements, or alternative tax reductions for small and medium-sized businesses. All these would provide substantially higher social and economic returns than perceived citizen benefits bound to energy consumption. Separate funds could have been spent targeting low-income households more effectively, for instance, through comprehensive social safety nets. In some MENA countries, the size of energy subsidies relative to other forms of expenditure is staggering. ${ }^{9}$ In Egypt, total government expenditure on energy subsidies in 2008 equalled combined expenditure on health and education; as did fuel subsidies in Jordan prior to the country's 2008 reform of fuel prices. Yemen's budgeted expenditure on fuel subsidies in 2008 amounted to more than 34 per cent of total government expenditure-more than one and a-half times the expenditure on education and health combined (Breisinger et al., 2011).

The widespread use of energy subsidies also affects the rate of investment in the energy sector in parts of MENA; the quality of coverage of different energy services, including fuel supply and electricity, consequently affects social groups differently. Caps on government subsidies paid to producers, or flat payment subsidies, often may not fully compensate domestic oil/gas producers, refineries, importers and distributors, and electricity producers for their incurred losses, and may undermine the rate of return on their investment. When funds are diverted away from state-owned enterprises and oil marketing companies and distributors, these companies will not be able to upgrade their internal capabilities, invest in new infrastructure, or shift to modern, cleaner, and more efficient technologies. The result is often the provision of low-quality services to end users, most visibly in the region's electricity sector.

Recurring power outages have characterised electricity provision throughout wide parts of MENA, typically due to decade-long underinvestment in electricity generation and in transmission and distribution networks. In many parts of the Levant and the Gulf, this situation is further exacerbated by a culture

9 The IMF reports that in about half of MENA countries, total pre-tax energy subsidies were higher than capital spending in 2011. In all oil exporters, total pre-tax energy subsidies exceeded spending on education and on health, while in Egypt, Jordan, and Lebanon spending on total pre-tax energy subsidies was higher than spending on capital, health, or education. In 2008, Egypt dedicated $11.93 \%$ of its gross annual expenditure to education, $5.94 \%$ to health, and an estimated $17.85 \%$ to fuel subsidies. Fattouh and El-Katiri (2012b). 
of non-payment of utility bills by some parts of the population. Recurring blackouts, seen in recent years across many parts of the Levant, Iraq, Egypt, and perhaps most paradoxically in several Gulf Cooperation Council (GCC) member states (Bahrain, Kuwait, Oman, Qatar, Saudi Arabia, and the United Arab Emirates (UAE)), are just one of the most visible consequences of lagging new investment and insufficient capacity across many parts of MENA. These blackouts proportionally affect middle-income households and small businesses significantly more than any other energy-consumer group. Long waiting times for new electricity connections for private households and businesses are often the consequence, resulting in annual losses in foregone business activity and backup costs for the economies concerned (World Bank, 2008).

For some of the poorest parts of MENA, however, the consequences of underinvestment and a lack of electricity grid access are staggering. Lack of electrification in remote areas can be seen primarily in Yemen and in some rural parts of Morocco. In Yemen, little more than half the population has access to electricity, as the chronically underfunded state utility has insufficient funds to invest in expanding the country's electricity grid and generation capacity (Breisinger et al., 2011; El-Katiri and Fattouh, 2011). Of those households with electricity access, which are entirely concentrated in the wealthier former North, nearly 70 per cent are on 'lifeline rates', supposedly enabling electricity access for low-income households. Yemen's case painfully illustrates the highly regressive nature of energy subsidies.

Continued significant fuel price differences between neighbouring countries in MENA, owing to different subsidy regimes, have also incentivised largescale fuel smuggling across borders. Fuel smuggling has been of particular concern among neighbouring countries in the Levant, such as Syria, Jordan, and Lebanon; between Egypt and the Palestinian territories; across the closed borders between Algeria and Morocco and between Tunisia and Libya (resulting from the 2011 uprisings) (Algerie DZ, 2008; France 24, 2011); into and from Iraq and neighbouring countries; and from and to Yemen (Wahab, 20o6; Ibrahim, 2011). Iran, with (up to end-2010) some of the world's lowest prices for fuel, has suffered from endemic cross-border fuel smuggling to all its neighbours, a problem also incurred by other Gulf States (Arab Times, 2011). Fuel smuggling not only contributes to illegal contraband trade at the expense of the domestic economy, but in many cases substantially exacerbates existing fuel shortages in subsidising countries, as seen most recently in Yemen (MEES, 2014h; Ghobari and El Gamal, 2014).

\subsection{Energy Subsidies and Domestic Energy Consumption}

While high revenues and foreign assets are currently shielding many of the MENA region's larger oil and gas exporters in the short term, energy exporters 
face a longer-term challenge related to the way in which their current pricing policies affect their domestic energy consumption. The pivotal role played by national hydrocarbon resources in the development of many large MENA oil and gas producers has deeply affected the way energy features as a critical component in the citizen-state relationship. Oil wealth has facilitated much of the modern-day socio-economic development in the region, particularly that of the very oil-rich Gulf monarchies. Rather than engaging in more democratic forms of government, many of these countries' traditional political systems are based on the state's central role as a distributor or allocator of wealth in return for political legitimacy (Luciani, 1987; El-Katiri, 2013a).

The perceived abundance of energy resources, guaranteed by the state, and coupled to the state's role as a provider for its citizens, has historically been enshrined in some of the world's lowest prices for fuel, natural gas, and electricity. These in-kind citizen benefits, which also fuelled many oil producers' industrial expansion towards energy-intensive industries during the 196os and 1970 , are supplemented by often generous welfare systems that have become an effective element in these states' political stability over several decades.

Low domestic energy prices have led to a surge in regional energy consumption-beyond the influence of such factors as economic and population growth. With regional energy consumption having more than quadrupled in less than 30 years (authors' calculations based on World Bank, 2014), the MENA region is now one of the world's fastest growing energy markets, and is forecast to become the second most important driving force of global energy demand after Asia in the period to 2040 (IEA, 2011; EIA, 2011). Saudi Arabia is already the world's twelfth-largest energy consumer, and the sixth-largest consumer of oil and natural gas, with oil consumption alone having more than doubled over the past ten years (based on BP and EIA statistics). Other large regional oil and gas producers in the Gulf follow this pattern, albeit with smaller populations, and are leading the world's league tables in terms of per capita living standards.

The fiscal problems arising from current consumption patterns that remain tied to current pricing policies in MENA's oil and gas producers in the long term are related to the way in which most of these states finance their spending. Many of these countries do not tax their domestic citizens, but finance themselves to an overwhelming extent on the basis of export revenues for their valuable oil and natural gas resources - the level of this dependence ranges from around 6o per cent of total government revenues in Qatar to over 9o per cent in countries such as Libya, Iraq, Kuwait, and Saudi Arabia (Fattouh and El-Katiri, 2012a, 3). A further increase in already generous welfare handouts (for background, see El-Katiri, L., 2013a; El-Katiri, M., 2013; Gause III, 2013) has also allowed the oil- and gas-rich Gulf monarchies to avoid Arab Spring-style political upheaval. This modus operandi works as long as sufficient volumes 
of hydrocarbon exports are available. However, some studies have shown that under the business-as-usual scenario (where domestic demand keeps increasing at a robust pace and the GCC governments fail to diversify their economies) export capability could be eroded, leading to a collapse of these countries' revenue base, with detrimental political consequences. ${ }^{10}$ Recent falling oil prices, if they persist, will make the need for an adjustment of spending patterns (including a reform of energy subsidies) increasingly urgent.

The MENA region's low energy prices have also had many unintended consequences, including the very high and (countering trends virtually everywhere else in the world) rising energy intensity of MENA economies, meaning that more energy per unit of economic output is needed in these economies than anywhere else in the world. ${ }^{11}$ This is partly because the concentration of economic activity around energy-intensive industries in MENA's oil-producing countries has diverted much investment from other economic sectors. However, the high energy intensity of MENA economies is also due to inefficiencies in energy use across the region..$^{2} \mathrm{~A}$ recent $\mathrm{AB} \mathrm{B}$ study, comparing energy efficiency rates in power generation across a range of countries globally, shows that MENA energy producers such as the UAE, Libya and Saudi Arabia are among the world's least energy-efficient countries in terms of domestic power generation

1o Simulations of Saudi Arabia's domestic oil demand, such as those conducted by Chatham House and Citibank, show the potential for Saudi Arabia-under a business-as-usual scenario - to exhaust its own domestic reserve base in just 15-20 years, turning itself ultimately into a net importer of oil, unless alternative policy options are pursued. (Lahn and Stevens, 2011; Daya and El Baltaji, 2012). See also El-Katiri, L. (2013b).

11 Total primary energy consumption per dollar of GDP (an indicator of energy intensity) over the past three decades has declined in all parts of the world, with the exception of MENA. Energy intensity growth rates in several MENA economies, including the UAE, Saudi Arabia and Oman, have risen particularly fast, more than tripling in the UAE and Saudi Arabia since 1980. This growth is not a Gulf phenomenon alone, however; energy intensity in several other economies, including Jordan, Egypt and Syria, also increased by more than a third over the same time period. Egypt and several Mashreq economiesincluding Jordan - whose industries are generally less energy intensive, still require over $40 \%$ more energy per unit of economic output than do some of the world's less energyintensive economies, such as Denmark or Spain. Fattouh and El-Katiri (2013).

12 In a recent article, Prince Abdulaziz Bin Salman Al-Saud argues that 'Although this growth in demand is partially attributed to the industrial growth and growing economic prosperity in the kingdom, a rather significant portion of it results from the inefficient use of energy; deeming this accelerated growth unsustainable. Whereas the vast majority of countries have managed to lower the energy intensity of their economies, the kingdom's energy intensity increased significantly over the last two decades. Hence, it is a strategic imperative for the kingdom that energy efficiency becomes a major topic for all decisions related to an increase in demand for fuel and feedstock'. (Al-Saud, Prince Abdulaziz Bin Salman, 2014, 4). 
(ABB, 2014). However, MENA's net-importers of energy, including Jordan, Lebanon and Morocco, fare little better, comparing unfavourably to other developing economies, including those in Latin America. Similar conclusions apply to the region's rapidly growing transport sector, where average fuel consumption per vehicle across the Middle East is more than twice the average of countries without fuel subsidies. ${ }^{13}$

Low energy prices for regionally produced oil and natural gas have also affected the composition of the MENA economies' domestic energy mix. While these economies have historically not faced the same incentives as consumer countries in Europe and North America to diversify their domestic energy mix away from fossil fuels (for domestic energy security reasons) they may well have overlooked the economic potential of alternative energies such as renewable energy sources and nuclear power, given the influence of some of the world's lowest domestic prices for fossil fuels (El-Katiri, 2014; El-Katiri and Husain, 2014). As a result, the MENA economies remain dependent on oil and natural gas for a staggering 95 per cent of their domestic energy needs; more than any other region in the world (El-Katiri (2014) based on World Bank (2014) data). Their lack of diversity in domestic energy sources has left many MENA energy importers exceptionally exposed to commodity price cycles and to surging world market prices for oil and natural gas.

Recent evidence from Kuwait shows that a realignment of prices at, or closer to, the market price level confers a benefit on current and future generations of Kuwaitis (in terms of fiscal savings) that outweighs the impact of raising consumers' electricity and water prices to market price levels. ${ }^{14}$ Such studies also underline the tremendous potential for economic savings to be made, including through the reduction of deadweight loss.

Although energy subsidies are an inefficient and regressive distribution method, their reduction or elimination is a delicate economic and political task that

13 Notably, the Middle East region in this context includes Iran, which until 2010 was widely cited as the single largest subsidiser of domestic fuels in the world. (Bressand et al., 2007).

14 See Fattouh and Mahadeva (2014). The authors show that in the market price scenario with consumer prices at about ten times current levels, there is a total fiscal cost of about a third of the value of fuel input used in the power sector (or about $1.5 \%$ of GDP), entirely due to the cash transfer. This, however, is just less than a fifth of the fiscal cost of the current low-price regime, and in principle represents a massive saving. The net benefit of moving to market prices is $6.3 \%$ of GDP. 
requires considerable skill and political will. Without appropriate compensatory programmes and without effective state capacity to provide public goods such as public transport networks and social welfare for the poorer segments of a society, energy price increases following reform will impact real incomes and could become a very potent source of public anger and social unrest. Notably, energy pricing reform affects not only the poor, but also the MENA region's aspiring middle class, and the region's industries. This is all the more concerning for oil and gas producing countries, whose industrial base is often highly energy intensive, and for whose populations the ownership of a car is a critical sign of social progress.

The economic lock-in effect of energy subsidies in MENA countries is further reinforced by strong coalition-building by groups who benefit from current pricing systems -in particular industrial groups, but also members of current sociopolitical elites, who tend to have little interest in supporting public spending reforms. The Arab Spring affected the region's political climate, deterring meaningful reform of domestic energy pricing policies across the MENA region due to widespread government concern that the fear of rising living costs, associated with subsidy reform, could stir up further popular discontent. Nevertheless, reform efforts have become much more common in MENA than expected, providing a wealth of experience around the 'how and when' of regional subsidy reform (Sdralevich et al., 2014, 44-55).

\subsection{Gradual Reform Efforts in the Levant and North Africa}

Fear of incitement of a popular backlash has kept those MENA countries that were largely unaffected by Arab Spring-style unrest cautious of energy pricing reform. In spite of remaining largely unaffected by street protests, in comparison with countries such as Egypt and Tunisia, Morocco and Jordan both rolled back reforms following the ousting of the Tunisian and Egyptian presidencies in 2011 and the outbreak of political protest across many other parts of the region. Both Morocco and Jordan are IMF debtors who, a few years previously, had initiated tentative reforms to reduce domestic energy subsidies. Jordan had, for instance, made several attempts to reform the domestic prices of food and energy - in 2008 its government announced a programme of domestic energy price liberalisation. However, the reform stalled and was reversed in January 2011, when the government decided to cut food and fuel prices in response to political protests seen in neighbouring countries. In an unexpected gesture of cross-regional solidarity between Arab monarchies, the wealthy GCC states extended an invitation to the kingdoms of Morocco and Jordan to join the Gulf Cooperation Council, and subsequently increased their level of assistance to both countries, in the form of advantageous loans and unconditional development aid. This helped both countries initially withstand calls from international 
lending organisations for further fiscal reforms (MEES, 2011; MEES, 2012a; MEES, 2013; MEES, 2014e).

A year on from the Arab Spring, however, domestic energy subsidy reform was back on the agendas of several North African and Levantine energy importers. Jordan's rapidly rising fuel imports-partly due to declining gas imports from Egypt, which has since been struggling to supply its own domestic market-subsequently contributed to a skyrocketing energy subsidy bill that eventually reached 40 per cent of total government spending. Faced with limited room for manoeuvre, the Jordanian government was forced to curb public spending significantly —including that on fuel subsidies — as part of a USD 2.05 billion standby arrangement with the IMF; one aim of this arrangement was to help the kingdom recover from the economic strains associated with the mass inflow of Syrian refugees, a result of the political crisis in neighbouring Syria (MEES, 2012c). But Jordan's reform efforts were not exclusively externally driven; the repercussions of the Arab Spring had made fiscal reforms practically unavoidable if political and economic stability were to be maintained. This was a small but significant turning point in the way in which many governments have since come to see energy subsidy reform.

Jordan's November 2012 decision to gradually lift all petroleum product subsidies-later followed by the lifting of LPG and electricity subsidies-was painful, and faced considerable opposition both in parliament and on Amman's streets. Street chants denouncing the Jordanian king led to a series of confrontations between protesters and the police. Having withstood this initial opposition, Jordan has since progressed with its reforms, following a gradual drying-up of popular opposition to them. The government's response included a series of television and newspaper interviews underlining the government's need to reduce the burden of subsidies, or otherwise 'face catastrophe and insolvency'.15 In an effort to mitigate the effects of fuel price increases on Jordanian families, the government announced that within a week of the reform poor Jordanian households (below an annual household income of USD 14,100 (Jordanian dinar (JOD) 10,000)) would receive a direct cash handout of USD 99 (JOD 70); in effect around 70 per cent of the population would receive cash transfers. Electricity tariffs for individual economic sectors and high-income households have been increased a further three times since May 2012-part of a strategy to ensure the return of the National Electric Power Company NEPCO, Jordan's national electric power company, to cost recovery over the medium term.

15 Prime Minister Abd Allah al-Nusur said, 'If the move [had been] delayed, we would have faced a catastrophe and insolvency'. (MEES, 2012c). 
The interim results of the reform have been largely positive; alongside other fiscal reforms, energy subsidy reforms helped reduce the Jordanian government's deficit from 14.5 per cent of GDP in 2011 to around 8.3 per cent of GDP in 2014. As a result, Jordan's access to lending from international capital markets has markedly improved (IMF, 2014a).

Morocco decided to freeze energy prices in 2011 in spite of the high and rising level of global oil prices and the country's dependence on imported energy for virtually all of its domestic energy needs. The move came largely as a direct response to popular protests in neighbouring North African countries and to - in small numbers and for a short period of time - protests on its own streets. This decision soon led to a rapidly ballooning energy subsidy bill. By the end of 2012, Morocco's energy subsidy bill had become

... almost the size of the overall fiscal deficit, as much as spending on investment, and more than the spending on health and education combined.

IMF, 2014b, 16

An initial round of energy price rises reduced the cost of subsidies by nearly half to-still—around USD 4.1 billion, or 10 per cent of government spending in 2013 (MEES, 2014f). Agreeing with the IMF to reduce the fiscal burden of subsidies in return for a USD 6.2 billion IMF Precautionary and Liquidity Line in August 2012, Morocco announced far-reaching domestic pricing reform for petroleum products between late 2013 and early 2014. Morocco's case is interesting as it is one of the few MENA countries that not only raised prices for domestic fuel products, but actually linked them on a permanent basis to international prices. Price adjustments are made twice monthly by the Ministry of General Affairs and Governance, independently from the ministries of Energy and of Electricity. ${ }^{16}$

In order to avoid any political backlash from this reform effort (having faced mass popular protests during the 1980 s when it attempted to raise prices for basic foodstuffs), Morocco implemented a comprehensive and fairly wellorchestrated communication strategy to accompany the reform. This included public TV and radio discussions, newspaper articles, advertisements, and debates explaining in remarkable and easily understood detail the economic reasons for the reform of prices, the different reform steps, the reason for linking prices to a regularly reviewed international price index, and the multiple

16 For the law governing this arrangement, see Royaume du Maroc (2013). 
benefits of reform to society as a whole ${ }^{17}$ (including the availability of more money for investment elsewhere ${ }^{18}$ ). The government also assured the population of what benefits would remain: electricity prices, already among the region's highest, initially remained unchanged, but were increased in July 2014 (nearly a year after the indexation system was launched) as part of the government's restructuring of the Office National de l'électricité (ONE); while LPG, used primarily as a cooking and heating fuel in Moroccan households, remains heavily subsidised.

The reform clearly targeted those people who, supposedly, could afford higher prices: industrial consumers, factories, and car drivers. Finally, the government emphasised that price indexation offered a fair deal on both sides: prices could increase, but would also fall when international prices decreased. The Moroccan reform effort was not met with a public outcry, and subsequently went largely unnoticed by international media. Key to enabling this notable success has been two consecutive governments that, despite varying party interests, were willing and able to build the necessary coalitions to enact the price increases, despite opposing views within their own ranks. The country's moderate Islamic party, the Parti de la justice et du développement (PJD), has notably been instrumental in rallying support for the reform, both within government and among the population. Morocco's total subsidies-including food, which had peaked in 2012 at 6.6 per cent of GDP, fell to around 3.9 per cent of GDP in 2013 (Verme et al., 2014).

\subsection{Yemen's Failed Reform Efforts}

Yemen illustrates the converse case, of domestic pricing reform efforts that have largely failed over several years. While these policies have been revised over time, in the most recent conflict they have proven to be additionally destabilising in an already heated political situation. By the end of 2010, subsidies for liquid fuels, LPG, and electricity had usurped around a third of state spending, more than the country's combined spending on health and education (Fattouh and El-Katiri, 2012b, 49). Yemen's subsidies overwhelmingly benefited the country's urban upper and middle classes, who have access to transport,

\footnotetext{
17 For an example of how the French-speaking urban middle classes were targeted, see Agueniou (2013).

18 A study of some past Moroccan publications aimed at younger audiences illustrates the government's line of argument. In Jeune Afrique, Ahmed Lahlimi, head of Morocco's High Planning Commission, cited the volume of petroleum product subsidies across several North and sub-Saharan African countries, concluding 'C'est effectivement problématique car cela représente autant d'investissements en moins pour le pays'. (Author's translation: ["These amounts of expenditure on fuel subsidies"] are highly problematic since they represent foregone investment') (Ballong, 2010).
} 
energy, and infrastructure links. Even today, around half the country (primarily the former South and the geographically remote provinces across Yemen's northern borders) lacks infrastructure; formal, price-controlled markets; and the ability to access the country's highly subsidised electricity grid. ${ }^{19}$ Yemen's severely deteriorating domestic security situation prior to and following the onset of the Arab Spring has led to a further deterioration in the country's finances. An increasing number of attacks on its oil and gas infrastructure have halted the country's hydrocarbon exports, adding to pre-existing domestic fuel shortages (MEES, 2014i; Saeed, 2014; MEES, 2014g).

Having had to import rising volumes of fuel products to cover shortfalls in domestic production, fiscal pressure on Yemen reached unprecedented levels; in a hasty and ill-prepared reform effort in July 2014, the country was forced (under intense pressure from lenders) to raise domestic energy prices. Amidst political turmoil, daily demonstrations in the streets of Sanaa and continued violent conflict between tribal groups and the central government in several provinces (many of which remain isolated from any electricity or fuel supply), the government's decision to raise domestic energy prices was seen as a further failure by the state to provide for its citizens (Abdullah, 2014). Yemen's weak central state has subsequently been unable to withstand pressure from nonstate groups - notably the Houthis - for a swift reversal of initial reform efforts (Security Council, 2014). This underlines the difficulty, if not impossibility, of reforming energy pricing once a state has failed fiscally and politically and has lost its credibility, and once its citizens' faith in its capabilities has collapsed.

Yemen's case also illustrates the enormous challenges that the region's weak states face in implementing subsidy reform. With the complex interrelationship between energy subsidies and economic efficiency, and the difficulty of communicating the value of suffering short-term pain (removal of energy subsidies) versus the desirability of achieving long-term gain (economic growth) to their populations, weak states are clearly in no position to reform energy subsidies. Even more so when they are faced with the need to respond to fiscal pressures, rather than being in a position to present a credible set of reforms that are aimed at improving people's livelihoods over the medium and long term. This difficulty, experienced by Yemen, is reflected in other contexts. For instance, AlKhatteeb and Istepanian describe the fear of reform in the case of Iraq, writing:

There was and still remains a general fear among the Iraqi officials that any radical economic reforms, such as the elimination of subsidies for basic necessities like kerosene, cooking gas, electricity, and food rations

19 El-Katiri and Fattouh $(2011,30-40)$ give an overview of access to electricity and different fuels across Yemen's provinces and income groups. 
would be faced with strong opposition by the public and might cause widespread rioting, destabilizing an already fragile political process.

AL-KHATTEEB and ISTEPANIAN, 2015, 4

\subsection{Egypt's 2014 Five-to-Midnight Reform}

Egypt offers an interesting counterexample to the Yemeni case. Having experienced political turmoil as part of the Arab Spring through not one but two subsequent changes of government, in addition to transitory government and years of instability, Egypt has nevertheless carried out a series of fuel and electricity price reforms since the election of President General al-Sisi. Fiscal pressure resulting from the country's spending on subsidies has been the main factor pushing Egypt's new government to engage in these reform efforts, despite the risk of popular unrest. ${ }^{20}$

While Egypt's July 2014 price hikes on most petroleum products were steep (up to 70 per cent price increases overnight), ${ }^{21}$ they have also been fairly successful in reducing the country's spending on oil subsidies (down to less than 7 per cent of total government spending in the planned budget for 2015/16, from a figure of 20 per cent back in 2012/13) (MEES, 2015). ${ }^{22}$ However, whilst spending on oil subsidies has fallen, spending on electricity subsidies has risen. Initial figures suggest that electricity subsidies are set to cost Egypt an estimated USD 3.42 billion (EGP 24.6 billion) for the fiscal year 2014/15, up 85 per cent on the 2013/14 figure of USD 1.84 billion (E GP 13.3 billion), though somewhat down on the original 2014/15 budget figure of USD 3.78 billion (EGP 27.2 billion) (MEES, 2015). The process of phasing the subsidy out is thus likely to be lengthy, although the government has been ambiguous on the timing and nature of future price rises. ${ }^{23}$ In addition, Egypt's declining natural gas production has meant that the country has had to import growing volumes of internationally sourced LNG, while natural gas continues to be sold to domestic consumers at prices far below the import cost.

20 For a background to Egypt's unfolding energy problem during the first decade of the twenty-first century, see Darbouche and Mabro (2011).

21 Diesel prices increased by $64 \%$, gasoline 80 by $77 \%$, and gasoline 92 by $41 \%$. However, these prices are still very low by international standards. See MEES (2014b).

22 Naturally, the decline in international prices for oil has also contributed towards this reduction in spending on subsidies.

23 According to the Financial Times the Egyptian government plans to phase out electricity subsidies over five years. The case of products is less clear, but the Minister of Planning has been quoted as saying that 'In five years fuel will be offered at 80 per cent of its real cost to sections of the population which are deemed to need subsidies, the rest will pay market prices'. (Saleh, 2014). 
These recent reform measures are bold by any standard, especially so in light of the political and social instability still engulfing Egypt, and reveal the extent of fiscal pressures and the limited choices faced by the Egyptian government. Defying many analysts' predictions, these price hikes, though very steep, have not resulted in mass protests and civil unrest. ${ }^{24}$ Part of the reason for this relates to timing. The reform measures were announced following a wave of nationalist fervour that saw President al-Sisi assume power, with strong support from his base for the onslaught against the Muslim Brotherhood. The violent crackdown on both the brotherhood and public protests may also have discouraged people from demonstrating. With hopes for a more stable future, for many Egyptians the prospect of paying higher prices for energy was arguably the lesser evil compared with the disastrous economic consequences of yet more political turmoil. The al-Sisi government may also have benefited from a much higher level of credibility than previous governments, promising a fairer socio-economic system and tying the reform of fuel and electricity prices to the unmistakeable need for financial resources to be used on essential services such as health and education. President al-Sisi, and Prime Minister Ibrahim Mahlab have been key proponents of the reforms, and have been personally engaged in communicating their necessity, using a series of media interviews to emphasise the need for common sacrifices in order to make Egypt 'great again' (Al Bawaba, 2014; Mubashir Misr, 2014).

While such factors can partly explain the muted response on the streets, the energy reforms' success will depend on the government's ability to introduce measures to mitigate the impact of high energy prices for the most vulnerable groups in society. Some such measures have, indeed, been introduced-the government freezing the prices of publicly distributed bread, rice, sugar, tea, flour and oil. The government has also expanded the food subsidy system, applying discounts to the prices of additional products such as meat and chicken. The price of LPG (widely used by low-income households) was not raised in the latest wave of reforms. Yet despite these mitigating measures, there is deep frustration among Egypt's low- and middle-income households related to the higher costs of living due to the price hikes. There is also scepticism about the government's ability to translate savings made thanks to the reforms into real benefits for the population (Rashwan, 2014).

Although the Egyptian government can be relieved that its initial reform steps did not cause mass protests, the road is long and key challenges remain.

24 There have been some small-scale protests and strikes (taxi drivers), but these were not widespread and did not threaten to destabilise the existing political system. (Fahim, 2014). 
Experience in other countries shows there is always the risk that the pace of reform slows down, or even that reforms are reversed. The government therefore needs to strengthen its currently highly ineffective social protection schemes and safety nets. For instance, in the case of ration cards, the World Bank has found that eligibility criteria (such as being retired or a public sector employee) are not pro-poor, leaving poor Egyptians less eligible for a high-subsidy ration card than are non-poor Egyptians. Also, these regressive eligibility criteria are not well enforced-more than two-thirds of those holding high-subsidy ration cards do not meet the requisite criteria to do so. ${ }^{25}$ The Egyptian government also has to establish credible commitments, including measures in areas such as public transport and infrastructure investment, laying the ground for the sound implementation of future price reforms.

Another issue to consider in the Egyptian case is the continued level of regulatory intervention in energy markets as a whole, given that Egypt has been adjusting prices on an ad hoc basis with no apparent plan in mind for future reform steps. One rationale for the current wave of reforms is that it will provide the government with the fiscal space needed to increase investment in public infrastructure and improve key services. In the absence of regular price adjustments, however, fluctuations in international energy prices may quickly erode current fiscal gains, further reducing the funds available for mitigation measures and public investment. For instance, the savings Egypt has made in the area of oil subsidies have partly resulted from the collapse of international oil prices since July 2014. Higher prices would reverse some of these savings and could force the government to adjust prices by engaging in highly visible political interventions, rather than by applying an automatic mechanism that helps reduce fuel subsidies.

\subsection{The Iranian Reform Experience}

Iran's targeted subsidy reform, initiated in 2010, is one of the most interesting cases the region has to offer. It is all the more significant as it has been conducted by a large oil and gas producing state that has, in the past, been perceived to be the most immune to calls for the rationalisation of domestic energy prices. The reform followed more than a decade of political controversy with regards to Iran's domestic oil prices, which were then among the lowest in the world. Surging domestic demand for energy, following more than a decade

25 Households in the top quintile receive subsidies of around $20 \%$ on the rationed products, compared with less than $16 \%$ for the lowest quintile. In terms of coverage, a third of the poor do not have ration cards, excluding them from the benefits of ration card subsidies. (World Bank, 2005). 
of international sanctions that had severely affected Iran's ability to produce from its enormous reserve base, had left the world's largest reserve holder of natural gas reliant on top-up imports to avoid power shortages and load shedding. Iran's domestic subsidy burden, measured on the basis of opportunity cost, was estimated to be around USD 100 billion by 2010 , an amount that exceeded the country's annual revenues from oil exports—at the time-of USD 70-8o billion (Guillaume et al., 2011, 4; Energy Compass, 2011; Tabatabai, 2011).

Iran's initial energy subsidy reform step, in December 2010, was estimated to have removed around USD 50-6o billion worth of subsidies (around 15 per cent of GDP) based on average 2010 international selling prices; this was achieved by dramatically raising the prices of such items as gasoline (300 per cent), natural gas (50 per cent), and diesel (90o per cent), virtually overnight (Energy Compass, 2011; Argus, 2013a). Within five years (coinciding with the country's Five-Year Plan) Iran's domestic energy prices should have risen to 90 per cent of their international market value. The architects of Iran's subsidy reform have been clear that price increases should be meaningful, in order to reduce demand effectively. Moreover, as outlined by some observers:

... relatively small domestic price increases could be rapidly eroded in real term by domestic inflation, an increase in international prices, or exchange rate depreciation.

GUILLAUME ET AL., 2011, 12

Finally, a front-loaded reform resulting in fast, large savings was a key requirement for the implementation of the Iranian government's single most important mitigation effort-a compensatory cash transfer system.

An essential part of Iran's strategy from the beginning was the redistribution, via cash grants, of proceeds generated by the reforms to different elements in the economy. Initial plans in 2010/11 included specific allocation targets: 30 per cent to domestic industries, in cash, to help them adjust to a gradually higher pricing environment (enabling energy efficiency-enhancing investments); 20 per cent to government institutions for similar adjustments; and 50 per cent to citizens, in the form of cash grants, to compensate households for generally higher living costs (Guillaume et al., 2011, 10). An initial plan to target lowerincome households with these cash transfers proved unworkable, so the government moved on to a universal cash transfer system with sums paid per adult to the head of each household. The sum-on average USD 180 for a household of four during the first six months of the reform-amounted to around half of the nation's minimum wage: a substantial benefit, particularly for those on low incomes (Tabatabai, 2011, 15). 
To further reduce the risk of widespread protest following these bold price rises, Iran's reform efforts were accompanied by a meticulously planned and executed public communication strategy, run by a government-appointed spokesman. Iranian news media (television, radio, websites and newspapers) and political, business, and social leaders and academics were all mobilised to speak in favour of the reform and to outline its many benefits to Iranian society. The campaign placed special emphasis on the background to the transformation - the enormous waste of Iranian natural and financial resources caused by the subsidy regime and the fact that the rich rather than the poor benefited most. The expected gains were also explained in detail-a universal cash transfer benefiting many poor households (Guillaume et al., 2011, 17-19; Tabatabai, 2011, 18-19). The entire communication strategy emphasised the shift of subsidies from products to people, a policy that would improve social equity, industrial competitiveness and economic diversification. To further counter the risks associated with the reform, the government widely advertised its policy of actively using monetary policy to counteract inflationary risks; prior to the reform, it also built up large stockpiles of basic goods to avoid bunkering and panic buying (Guillaume et al., 2011, 11).

Iran's subsidy reform has not been without complications. International sanctions (tightened significantly, and acting as a considerable restriction on oil exports since mid-2012), and the accompanying steep fall in the country's currency exchange rate, have created a surge in Iranian living costs and significantly complicated the efforts towards transformation; a second phase of the subsidy reform, planned for October 2012, has been suspended (MEES, 2012b).

In the run-up to presidential elections in 2013, the clear political value of Iran's cash transfer system also meant that the system-intended only initially to be universal-became a major issue in a political tug of war between different camps. Iranian politicians and oil and gas business leaders criticised the country for continuing to pay near-universal cash transfers that the system was increasingly unable to afford - the popularity of the scheme had seen the government keep handing out universal transfers at levels that soon exceeded the net savings it was making, with little left for other intended recipients such as industry. ${ }^{26}$

A new round of price increases, coupled with a reduction in monthly cash transfers to households, was initiated in early 2014, with the intention

26 Iran's Oil Minister, Bijan Namdar Zanganeh, has vociferously criticised Iran's cash transfer system, saying the Iranian oil and gas sector (from which the majority of revenues for the system come) could not afford to pay the handouts that were increasingly threatening domestic, upstream and refining companies' development projects (Argus, 2013a; Argus, 2013b). 
of achieving combined savings of around USD 19.1 billion in the Iranian year 2014/15 (MEES, 2014C; MEES, 2014d).

A systematic evaluation of the impact of Iran's price reform on consumption is difficult due to the presence of various other factors including the intensification of international sanctions against the country in mid-2012; sanctions that have affected Iran's oil exports. Furthermore, demand for electricity, and for natural gas in particular, are highly supply-driven, implying that shortfalls in the supply of these commodities in some provinces may translate into reduced demand growth even where price effects would not have indicated a steep fall in consumption. Among Iranian observers, some general agreement has emerged that the initial energy price rises in 2010 reduced fuel product and natural gas demand significantly in the following months, although the effect in subsequent months is less clear (IOD, 2011; Amuzegar, 2012). The main lesson to draw from the Iranian case, however, is the political feasibility of even a radical reform process if it is accompanied by sufficient planning, and makes use of an approach that provides a credible reform framework in the form of government commitments to facilitating the switch towards greater energy efficiency, coupled to a well-designed mitigation scheme that offers cash, rather than in-kind, benefits.

\section{$4 \quad$ Conclusions}

The reform of energy subsidies in MENA remains an economically and politically delicate task, one from which many of the region's governments still shy away, for several reasons. The Arab Spring has added a further, interesting variable to the region's energy subsidy dilemma, for it has instilled in many of the region's governments an even greater fear of the Arab street, including in countries that have remained largely unaffected by the political turmoil that has unfolded across the region since late 2010. Initially a complicating factor that has significantly delayed plans for energy pricing reform in the region since that turmoil began, the lessons of the Arab Spring could also provide an important underlying measurement against which governments can systematically reassess the way they spend national resources within their domestic economies, and a way of both the poor and the middle class receiving a better deal than has been offered in the past. ${ }^{27}$

27 Some recent, country-focused papers have started to explore various avenues for change (Kandil, 2010; Verme et al. 2014; World Bank, 2011). Verme et al. (2014) specifically model the effect a further subsidy reduction, combined with a universal cash grant, could have on poverty levels in Morocco. 
In the short term, however, rather than questions of wider social justice, the energy subsidy reform agenda in MENA will likely be dominated by questions of fiscal sustainability. The manner in which the fiscal burden of energy subsidies has spiralled out of control in recent years will render their reform increasingly unavoidable in a growing number of MENA economies-mainly energy importers and small-sized oil and gas producers such as Jordan, Lebanon, Egypt, Syria and Yemen. This is undoubtedly the most unsatisfactory path towards reform, and the long-term success of current policies - most of which have been implemented on an ad hoc basis under pressure from international lending organisations at times of severely compromised government capacity in a number of conflict-ridden MENA states-stands in marked contrast to the more desirable objective of comprehensively overhauling social security and equity issues throughout the MENA region. Striking the right balance between these parallel objectives will undoubtedly prove critical to determining the eventual success of energy subsidy reform, beyond mere fiscal savings for cash-strapped governments.

The importance of government credibility and capacity to mitigate the negative effects of energy subsidy reform on domestic customers has been made painfully clear in cases where energy price reforms have led to counterproductive outcomes, which has been the case-for example - in Yemen. The Yemeni case, as well as positive examples of reform efforts in countries such as Jordan, Morocco, Egypt and Iran, suggests that it is better to reform energy subsidies before a political or economic crisis point is reached. The fiscal discipline required for such endeavours may still prevent many MENA governments from initiating such comprehensive fiscal reform efforts proactively, and without immediate pressure from international lending bodies. In the medium and long terms, however, rationalising the way in which energy and fiscal resources are spent domestically will become an ever more critical element in ensuring the political and economic stability that these states ultimately seek.

The Iranian example is an important one, as it has demonstrated that a reform of domestic energy pricing can be economically and politically feasible for large oil and gas producers. Iran's unique features-including a large, heterogeneous population and geography, relatively large gaps between rich and poor, and additional complicating factors such as the presence of intensifying international sanctions - further strengthen the country's experience as a case in point. Many of the Gulf's other oil and gas producers-wealthy both in absolute and per capita terms-are equipped with even more powerful fiscal resources with which to enact the necessary mitigation measures to ensure a more rational use of their valuable oil and gas resources over the long term. In this context, the UAE's August 2015 move to deregulate domestic fuel prices 
sends an encouraging message in view both of the consistency with which the reform has been carried out, and the complete absence of any political turmoil during the first round of gasoline price increases (of up to almost 25 per cent) (The National, 2015). In view of the need for many more of the region's governments to accommodate the rising economic and political aspirations of their populations (which are becoming increasingly younger and better educated), the reform of energy pricing mechanisms, together with the provision of more effectively targeted benefits for their citizens, should arguably be an urgent priority for many MENA countries.

\section{References}

ABB (2014) The State of Global Energy Efficiency. Global and Sectoral Energy Efficiency Trends, Researched and written by Enerdata, Ав В Ltd, www.abb-energyefficiency .com/assets/documents-download/ABB-Trends-in-global-energy-efficiency-2013 .pdf (accessed on January 2015).

Abdih, Y., P. Lopez-Murphy, A. Roitman and R. Sahay (2010) The Cyclicality of Fiscal Policy in the Middle East and Central Asia: Is the Current Crisis Different?, IM F Working Paper No. 10/68, March, http://www.imf.org/external/pubs/ft/wp/2010/wp1o68 .pdf (accessed on 22 March 2016).

Abdullah, K. (2014) Army breaks up protests as Yemen raises fuel prices, Reuters, 30 July, http://uk.reuters.com/article/uk-yemen-budget-subsidies-idUKKBNoFZiFo2014 0730 (accessed on 22 March 2016).

Agueniou, S. (2013) 'Comment fonctionnera l'indexation des prix des produits pétroliers', La Vie Éco, 16 September (Casablanca: La Vie Eco Press) www.lavieeco.com/ news/economie/comment-fonctionnera-l-indexation-des-prix-des-produits-petro liers-26546.html (accessed on September 2014).

Al Bawaba (2014) 'Ra'is al-wuzara' al-masri juhawilu tabrira ziadah asa'ar al-wuqud' ('Egyptian Prime Minister tries to justify fuel price rise', in Arabic), Al Bawaba, 5 July (Amman: Al Bawaba Middle East Limited).

Al-Khatteeb, L. and Istepanian, H. (2015) Turn a Light On: Electricity Sector Reform in Iraq. (Washinton DC: The Brookings Institution) Retrieved from http://www .brookings.edu/ /media/research/files/papers/2015/03/18-electricity-sector-reform -iraq-alkhatteeb-istepanian/alkhatteeb-istepanian-english-pdf.pdf (accessed on August 2015).

Al-Saud, Prince Abdulaziz Bin Salman (2014) 'A brief on Saudi Arabia's Energy Efficiency Program (seEP)', Oxford Energy Forum, Issue 96, May, 4 (Oxford: The Oxford Institute for Energy Studies) https://www.oxfordenergy.org/wpcms/wp-content/ uploads/2014/o6/OEF-96.pdf (accessed on 21 March 2016). 
Alderman, H. (2002) Subsidies as a Social Safety Net: Effectiveness and Challenges, Social Protection Discussion Paper Series, 0224 (Washington, DC:World Bank), http:// siteresources.worldbank.org/SOCIALPROTECTION/Resources/SP-Discussion-pa pers/Safety-Nets-DP/o224.pdf (accessed on 22 March 2016).

Algerie DZ (2008) 'Contrebande d'essence entre l'Algérie et le Maroc', Algerie DZ, 2 July, http://www.algerie-dz.com/article1436o.html (accessed on 22 March 2016).

Amuzegar, J. (2012) 'Iran's Subsidies Reform: A Year Later', Middle East Economic Survey, 30 January (Cyprus: Middle East Petroleum and Economic Publications).

Arab Times (2011) 'Subsidized fuel smuggling costs Kuwait KD 245m yearly', Arab Times, 17 November, (Kuwait: Arab Times).

Argus (2013a) 'Iran fuel subsidies under new scrutiny', Petroleum Argus, 28 October.

Argus (2013b) 'Iran oil industry feels pinch of subsidy reforms', Petroleum Argus, 19 November.

Ballong, S. (2010) 'Carburant: vers la fin des subventions', Jeune Afrique, 13 July (Paris: Jeune Afrique).

Breisinger, C., W. Engelke and O. Ecker (2011) Petroleum Subsidies in Yemen: Leveraging Reform for Development, IF PR I Discussion Paper 01071 (Washington, DC: IF PRI), March, http://citeseerx.ist.psu.edu/viewdoc/download?doi=10.1.1.226.7675\&rep=re p1\&type $=$ pdf $($ accessed on 22 March 2016).

Bressand, F., D. Farrell, P. Haas, F. Morin, S. Nyquist, J. Remes, S. Roemer, M. Rogers, J. Rosenfeld and J. Woetzel (2007) Curbing Global Energy Demand Growth: The Energy Productivity Opportunity, McKinsey Global Institute, May, p. 15, http://www.mck insey.com/ /media/McKinsey/Business\%2oFunctions/Sustainability\%2oand\%20 Resource\%2oProductivity/Our\%2oInsights/Curbing\%2oglobal\%2oenergy\%2o demand\%2ogrowth/MGI_Curbing_Global_Energy_Demand_full_report.ashx (Accessed on 22 March 2016).

Clements, B.J., S. Gupta and H.-S. Jung (2003) Real and distributive effects of petroleum price liberalization: The case of Indonesia, IMF Working Papers 03/204, (Washington, DC: International Monetary Fund), https://www.imf.org/external/pubs/cat/lon gres.aspx?sk=16882.o (Accessed on 22 March 2016).

Coady, D., I. Parry, L. Sears, and B. Shang (2015), How Large Are Global Energy Subsidies?, WP15/105, (Washington DC: International Monetary Fund), https:// www.imf.org/external/pubs/ft/wp/2015/wp15105.pdf (Accessed on 21 March 2016).

Coady, D.P., M. El Said, R. Gillingham, K. Kpodar, P. Medas and D. Newhouse (2006) The Magnitude and Distribution of Fuel Subsidies: Evidence from Bolivia, Ghana, Jordan, Mali, and Sri Lanka, IMF Working Paper, 06/247 (Washington, DC: International Monetary Fund), https://www.imf.org/external/pubs/ft/wp/2006/wpo6247.pdf (Accessed on 21 March 2016).

Collier, P. and A. Hoeffler (1998) On economic causes of civil war, Oxford Economic Papers, 50 (1998), pp. 563-573, DoI: 10.1093/oep/50.4.563. 
Darbouche, H. and R. Mabro (2011) 'Egypt's Natural Gas Market: So Far So Good But Where To Next?' in Fattouh, B. and J. Stern (eds.) Natural Gas Markets in the Middle East and North Africa (Oxford: Oxford University Press), pp. 125-161.

Daya A. and D. El Baltaji (2012) Saudi Arabia May Become Oil Importer by 2030, Citigroup Says, (New York: Bloomberg), 4 September, http://www.bloomberg.com/news/ articles/2012-09-04/saudi-arabia-may-become-oil-importer-by-2030-citigroup -says-1- (accessed on 22 March 2016).

de Moor, A. and P. Calamai (1997) Subsidizing Unsustainable Development, Earth Council and the Institute for Research on Public Expenditure, p. 1., www.cbd.int/doc/ case-studies/inc/cs-inc-earthcouncil-unsustainable-en.pdf (accessed on July 2012).

EIA (US Energy Information Administration) (2011) International Energy Outlook 2011 (Washington DC: us Energy Information Agency).

El-Katiri, L. (2013a) 'The Guardian State and its Economic Development Model', Journal of Development Studies, 26 November, pp. 22-34, DOI: 10.1080/00220388.2013.849340.

El-Katiri, L. (2013b) Energy Sustainability in the Gulf: The Why and the How, oIEs Paper MEP4, (Oxford: The Oxford Institute for Energy Studies) http://www.oxfordenergy .org/wpcms/wp-content/uploads/2013/03/MEP_4.pdf (accessed on July 2015).

El-Katiri, L. (2014) A Roadmap for Renewable Energy in the Middle East and North Africa, oiEs Paper, MEP 6 (Oxford: The Oxford Institute for Energy Studies) http:// www.oxfordenergy.org/wpcms/wp-content/uploads/2014/o1/MEP-6.pdf (accessed on July 2015).

El-Katiri, L. and B. Fattouh (2011) Energy Poverty in the Arab World: The Case of Yemen, MEP 1 (Oxford: The Oxford Institute for Energy Studies) http://www.oxfordenergy .org/wpcms/wp-content/uploads/2011/o8/MEP_1.pdf (accessed on July 2015).

El-Katiri, L. and M. Husain (2014) Prospects for Renewable Energy in Gcc States: Opportunities and the Need for Reform, OIEs Research Paper MEP 10 (Oxford: The Oxford Institute for Energy Studies) http://www.oxfordenergy.org/wpcms/wp-content/up loads/2014/o9/MEP-10.pdf (accessed on July 2015).

El-Katiri, L., B. Fattouh and P. Segal (2012) 'Anatomy of an Oil-Based Welfare State: Rent Distribution in Kuwait' in: Held, D. and Coates-Ulrichsen, K. (eds.) The Transformation of the Gulf States: Politics, Economics and the Global Order (London: Routledge), pp. $165^{-186 .}$

El-Katiri, M. (2013) The Future of the Arab Gulf Monarchies in the Age of Uncertainties, (Carlisle, Pennsylvania: U.S. Army War College Strategic Studies Institute), June.

Energy Compass (2011) 'Iran: Biting the Bullet', Energy Compass, 14 January.

Erbil, N. (2011) Is Fiscal Policy Procyclical in Developing Oil-Producing Countries?, IMF Working Paper, WP/11/171 (Washington DC: International Monetary Fund) https:// www.imf.org/external/pubs/ft/wp/2011/wp11171.pdf (accessed on 22 March 2016).

Fahim, K. (2014) 'Egypt Cuts Tax Breaks for Fuel; Few Protest', New York Times, 17 July, http://www.nytimes.com/2014/07/18/world/middleeast/egypt-cuts-tax-breaks-for -fuel-few-protest.html?_r=o (accessed on 22 March 2016). 
Fattouh, B and L. Mahadeva (2014) Price Reform in Kuwait's Electricity and Water Sector-Assessing the Net Benefits in the Presence of Congestion, oIEs Paper, MEP 9, (Oxford: The Oxford Institute for Energy Studies) http://www.oxfordenergy.org/ wpcms/wp-content/uploads/2014/04/MEP-9.pdf (accessed on May 2015).

Fattouh, B. and L. El-Katiri (2012a) Energy and Arab Economic Development, Arab Human Development Report Research Paper Series, (New York: UndP Regional Bureau for Arab States), http://www.arab-hdr.org/publications/other/ahdrps/ENG FattouhKatiriV2.pdf (accessed on May 2015).

Fattouh, B. and L. El-Katiri (2012b) Energy Subsidies in the Arab World, Arab Human Development Report Research Paper, (New York: UNDP Regional Bureau for Arab States) http://www.arab-hdr.org/publications/other/ahdrps/Energy\%2oSubsidies -Bassam\%2oFattouh-Final.pdf (accessed on May 2015).

Fattouh, B. and L. El-Katiri (2013) 'Energy Subsidies in the Middle East and North Africa' Energy Strategy Reviews, 2:1, June 2013, pp. 108-115, D OI: 10.1016/j.esr.2012.11.004.

France 24 (2011) 'La contrebande vers la Libye assèche les pompes à essence dans l'Est algérien', (Paris: France 24), 11 August, http://observers.france24.com/fr/20110810 -contrebande-vers-libye-asseche-pompes-essence-est-algerien-tebessa-penurie -essence-tunisie (accessed on 22 March 2016).

Gause F.G. III (2013) Kings for All Seasons: How the Middle East's Monarchies Survived the Arab Spring, Brookings Doha Center Analysis Paper (Washington DC and Doha: The Brookings Institution), http://www.brookings.edu/ /media/Research/ Files/Papers/2013/o9/24-resilience-arab-monarchies-gause/Resilience-Arab-Mon archies_English.pdf?la=en (accessed on 22 March 2016).

Ghobari, M. and El Gamal, R. (2014) Army breaks up protests as Yemen raises fuel prices, Reuters, 30 July, http://uk.reuters.com/article/uk-yemen-budget-subsidies -idUKKBNoFZiFo20140730 (accessed on 22 March 2016).

Guillaume, D., R. Zytek, and M.R. Farzin (2011) Iran-The Chronicles of the Subsidy Reform, IMF Working Paper, WP/11/167, (Washington, DC: International Monetary Fund), https://www.imf.org/external/pubs/ft/wp/2011/wp11167.pdf (accessed on 22 March 2016).

Gupta, S., B. Clements, K. Fletcher and G. Inchauste (2003) 'Issues in Domestic Petroleum Pricing in Oil-Producing Countries', in Davis, J., R. Ossowski and A. Fedelino (eds.), Fiscal Policy Formulation and Implementation in Oil-Producing Countries (Washington, DC: International Monetary Fund).

Hope, E. and B. Singh (1999) Energy Price Increases in Developing Countries: Case Studies of Colombia, Ghana, Indonesia, Malaysia, Turkey, and Zimbabwe, World Bank Policy Research Working Paper No. 1442 (Washington DC: World Bank), DOI: 10.1596/1813-9450-1442.

Ibrahim, L. (2011) Syria to Raise Fuel-Oil Price to Limit Smuggling, (New York: Bloomberg), 10 August, http://www.bloomberg.com/news/articles/2011-08-10/syria-to -raise-fuel-oil-price-to-limit-smuggling-thawra-says (accessed on 22 March 2016). 
IEA (International Energy Agency) (2011) World Energy Outlook 2011 (Paris: OECD/IEA), 696 p, http://www.worldenergyoutlook.org/weo2011/ (accessed on 22 March 2016). IEA, OPEC, OECD, and World Bank. (2010) Analysis of the Scope of Energy Subsidies and Suggestions for the G-2o Initiative, Joint Report prepared for submission to the G-20 Summit Meeting Toronto (Canada), June 2010, https://www.oecd.org/env/4909o716. pdf (accessed on 22 March 2016).

IMF (International Monetary Fund) (2013) Regional economic outlook: Asia and Pacific (Washington, DC: International Monetary Fund).

IMF (International Monetary Fund) (2014a) Jordan. Article IV Consultation, Third and Forth Review under the Stand-By Arrangement, Request for Wavers of Non-observance of Performance Criterion and Applicability of Performance Criterion-Staff Report; Press Releases; and Statement by the Executive Director for Jordan. IM F Country Report No. 14/152, June 2014, https://www.imf.org/external/pubs/ft/scr/2014/cri4152 .pdf (accessed on 22 March 2016).

IMF (International Monetary Fund) (2014b) Morocco. Article IV Consultation Staff Report; Press Releases; and Statement by the Executive Director for Morocco. IMF Country Report No.14/65, March, https://www.imf.org/external/pubs/ft/scr/2014/cr1465 .pdf (Accessed on 22 March 2016).

IOD (International Oil Daily) (2011) 'Price Hikes Squeeze Iranian Gasoline Demand', International Oil Daily, (New York, London: Energy Intelligence Group) 17 January.

Kaminsky, G.L., C.M. Reinhart and C.A. Vegh (2004) When it rains, it pours: Pro-Cyclical Capital Flows and Macroeconomic Policies, Working Paper 10780, National Bureau of Economic Research, www.nber.org/papers/w10780.pdf (accessed on September 2014).

Kandil, M. (2010) The Subsidy System in Egypt: Alternatives for Reform, Policy Viewpoint Series, (Cairo: The Egyptian Centre for Economic Studies (ECES)), December, http://www.eces.org.eg/MediaFiles/Uploaded_Files/\%7B1oD14532-9640-4DCE -A76E-EBAD724A51D4\%7D_PVP25-Eng.pdf (accessed on 22 March 2016).

Lahn, G. and P. Stevens (2011) Burning Oil to Keep Cool. The Hidden Energy Crisis in SaudiArabia, (London: The Royal Institute of International Affairs, Chatham House), December, https://www.chathamhouse.org/sites/files/chathamhouse/ public/Research/Energy,\%2oEnvironment\%20and\%2oDevelopment/1211pr_lahn _stevens.pdf (accessed on 22 March 2016).

Lane, P.R. (2003) 'The cyclical behaviour of fiscal policy: evidence from the oECD', Journal of Public Economics, 87(12), pp. 2661-2675, DOI: 10.1016/Soo47-2727(02)00075-0.

Luciani, G. (1987) 'Allocative versus production states: a theoretical framework' in Beblawi, H. and G. Luciani (eds.) The Rentier State (London: Croom Helm), pp. 63-82. MEes (Middle East Economic Survey) (2011) ‘Gcc Endorses King 'Abd Allah's Call To Achieve Union' Middle East Economic Survey, 26 December.

MEes (Middle East Economic Survey) (2012a) 'Arab Fund Chief Pledges Continued Support In Wake Of Arab Spring' Middle East Economic Survey, 16 April. 
MEES (Middle East Economic Survey) (2012b) 'Iran Suspends Subsidy Cuts, Slashes Budget', Middle East Economic Survey, 2 October.

meEs (Middle East Economic Survey) (2012c) 'Jordan's Energy Price Hike Triggers Protests', Middle East Economic Survey, 16 November.

MEEs (Middle East Economic Survey) (2013) 'GCC Aid Flows To Bahrain And Morocco' Middle East Economic Survey, 1 March.

MEES (Middle East Economic Survey) (2014a) 'Egypt looks to Reform to Attract Investment, Boost Growth', Middle East Economic Survey, 18 July.

mees (Middle East Economic Survey) (2014b) 'Egypt Price Hikes Push Inflation Rate to 10.6\%', Middle East Economic Survey, 15 August.

MEEs (Middle East Economic Survey) (2014c) 'Iran Advances Subsidies Reform' Middle East Economic Survey, 28 February, 57(09).

meEs (Middle East Economic Survey) (2014d) 'Iran Kicks Off Phase II Of Subsidy Reform', Middle East Economic Survey, 25 April.

meEs (Middle East Economic Survey) (2014e) 'Morocco Bags IMF, EU, Qatari Cash', Middle East Economic Survey, 1 August.

meEs (Middle East Economic Survey) (2014f) 'Morocco Targets Further Subsidy Reductions' Middle East Economic Survey, 21 March.

MEEs (Middle East Economic Survey) (2014g) 'Yemen Mired In Fuel Subsidy Dilemma', Middle East Economic Survey, 23 May.

meEs (Middle East Economic Survey) (2014h) 'Yemen Oil Minister Replaced As Fuel Crisis Deepens' Middle East Economic Survey, 20 June.

meEs (Middle East Economic Survey) (2014i) 'Yemen: 2014 Budget Looks To Patch Holes In Violence-Fueled Revenue Slump', Middle East Economic Survey, 24 January. meEs (Middle East Economic Survey) (2015) 'Egypt Lays Out Further Subsidy Cuts For 2015-16 But Overall Spending Up', Middle East Economic Survey, 26 June.

Mubashir Misr (2014) 'Al-Sisi jubariru ziadat al-asa'ar ... wa juhadhiru min al-irhab' ('Al-Sisi justifies fuel price rise... and warns of terrorism', in Arabic), Mubashir Misr, 7 July.

Rashwan, N. (2014) 'Voices from Egypt: How will increased energy prices affect you?', Middle East Eye, 6 July, http://www.middleeasteye.net/news/voices-egypt-how-will -new-energy-prices-affect-you-1738307315 (accessed on 22 March 2016).

Royaume du Maroc (2013) Bulletin Officiel du 5 septembre, No.1686, http://81.192.52.100/ BO/FR/2013/BO_6184_Fr.pdf (accessed on September 2014).

Saeed, A. (2014) 'Ministry of Oil: Fuel subsidy partially to blame for shortage', Yemen Times, 6 May.

Saleh, H. (2014) 'Egypt sharply raises energy prices', Financial Times, 5 July, https://next .ft.com/content/o8576doo-043f-11e4-ab6a-00144feab7de (Accessed on 22 March 2016). 
Sdralevich, C., R. Sab, Y. Zouhar and G. Albertin (2014) Subsidy Reform in the Middle East and North Africa Recent Progress and Challenges Ahead, IMF Middle East and Central Asia Department (Washington, Dc: International Monetary Fund), http:// www.imf.org/external/pubs/ft/dp/2014/1403mcd.pdf (accesssed on 22 March 2016). Security Council (2014) Yemen: October 2014 Monthly Forecast, un Security Council Report, 30 September, http://www.securitycouncilreport.org/monthly-forecast/ 2014-10/yemen_11.php (accessed on October 2014).

Tabatabai, H. (2011) The Basic Income Road to Reforming Iran's Price Subsidies, Basic Income Studies, 6:1, pp. 1-24.

The National (2015) 'UAE fuel prices for August announced' The National, 28 July, (Abu Dhabi: The National) http://www.thenational.ae/uae/transport/uae-fuel-prices -for-august-announced (accessed on August 2015).

Verme, P., K. El-Massnaoui and A. Araar (2014) Reforming Subsidies in Morocco, Economic Premise 134 (Washington DC: World Bank), http://www-wds.worldbank .org/external/default/WDSContentServer/WDSP/IB/2014/o2/o6/ooo333037_201402 o6144354/Rendered/PDF/84516oBRIooBox382123BooPUBLICooEP134.pdf (accessed on 22 March 2016).

Wahab, B.A. (2006) 'How Iraqi Oil Smuggling Greases Violence', Middle East Quarterly, Fall 2006, pp. 53-9, http://www.meforum.org/1020/how-iraqi-oil-smuggling-greases -violence (accessed on 22 March 2016).

World Bank (2005) Egypt-Towards a More Effective Social Policy: Subsidies and Social Safety Net, Social and Economic Development Group, NO. 33550-EG, 16 December, (Washington DC: World Bank). http://siteresources.worldbank.org/INTPSIA/Re sources/490023-1171551075650/Egypt_PSIA_121605.pdf (accessed on 22 March 2016).

World Bank (2008) Republic of Lebanon. Electricity Sector Public Expenditure Review, Report No. 41421-LB (Washington DC: World Bank), http://siteresources.world bank.org/INTMNAREGTOPENERGY/Resources/LebanonElectricityPER.pdf (accessed on 22 March 2016).

World Bank (2011) Electricity Subsidies and Household Welfare in Jordan: Can households afford to pay for the budget crisis?, Background paper for the Jordan Poverty Reduction Strategy (Amman: Hashemite Kingdom of Jordan) http://inform.gov.jo/Link Click.aspx?fileticket=srsTqsTılQM\%3d\&portalid $=0$ \&language $=$ en-US $($ accessed on 22 March 2016).

World Bank (2014) Database of World Development Indicators, (Washington DC: World Bank), http://data.worldbank.org/data-catalog/world-development-indica tors (accessed on January 2015). 